\title{
In Memoriam - Prof. Stefan Raszeja MD PhD
}

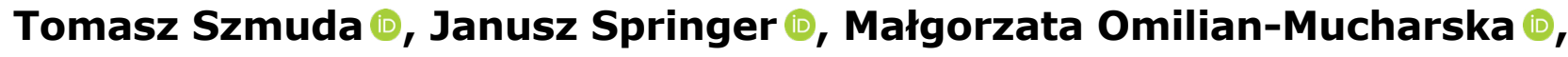 \\ Justyna Fercho $\oplus^{\circ}$, Izabela Szeibelis-Deskiewicz $\oplus^{\circ}$, Dariusz Kozłowski
}

European Journal of Translational and Clinical Medicine, Publishing Office, Medical University of Gdańsk, Poland

Keywords: Stefan Raszeja · Medical University of Gdańsk · ethics · editorial · in memoriam

\section{Citation}

Szmuda T, Springer J, Omilian-Mucharska M, Fercho J, Szeibelis-Deskiewicz I, Kozłowski D. In Memoriam - prof. Stefan Raszeja MD PhD. Eur J Transl Clin Med. 2021;4(1):7-9.

DOI: $10.31373 /$ ejtcm/136660

On March 10, 2021, professor Stefan Raszeja passed away at age of almost 100 . Since 1970, he was the founder and Editor-In-Chief of Annales Academiae Medicae Gedanensis, the scientific journal published by the Medical University of Gdańsk. Currently, the European Journal of Translational and Clinical Medicine (EJTCM) continues, albeit in an updated format, the remarkable legacy of its Founder with utmost respect. From the beginning, prof. Raszeja appreciated and supported the endeavours of Medical University of Gdańsk authorities to help Annales enter a place on the prestigious Impact Factor Master Journal List [1]. Today, we humbly announce a partial achievement of prof. Raszeja's dream: the EJTCM is indexed in the Scopus database [2]! The publishing market remains highly competitive, thus constant adjustments of the EJTCM are needed. Not forgetting the long-time aspirations of the Publisher, the past, current and future Editors of our journal stand in front a formidable challenge, regrettably without the support of prof. Raszeja. His experience on the Editorial Board of the American Journal of Forensic Medicine and Pathology helped prof. Raszeja to lay the organisational foundations for Annales Academiae Medicae Gedanensis, and thus ultimately and unnoticeably contributed to current shape of EJTCM. In our editorial work we draw from his numerous achievements, which all together are difficult to concisely summarise. All of his innovations are inspiring and somewhat transgressing the

Corresponding author:

prof. Dariusz Kozłowski, PhD, MD, Department of Cardiology and Electrotherapy, Medical University of Gdańsk, Poland

e-mail: dariusz.kozlowski@gumed.edu.pl

Funding: No external funds

Available online: www.ejtcm.gumed.edu.pl

$\underset{\substack{\text { TRANSPARENT } \\ \text { PROCESS }}}{\substack{\text { OPEN } \\ \text { ACCESS }}}$

Copyright ${ }^{\circledR}$ Medical University of Gdańsk

This is Open Access article distributed under the terms of the Creative Commons Attribution-ShareAlike 4.0 International. 


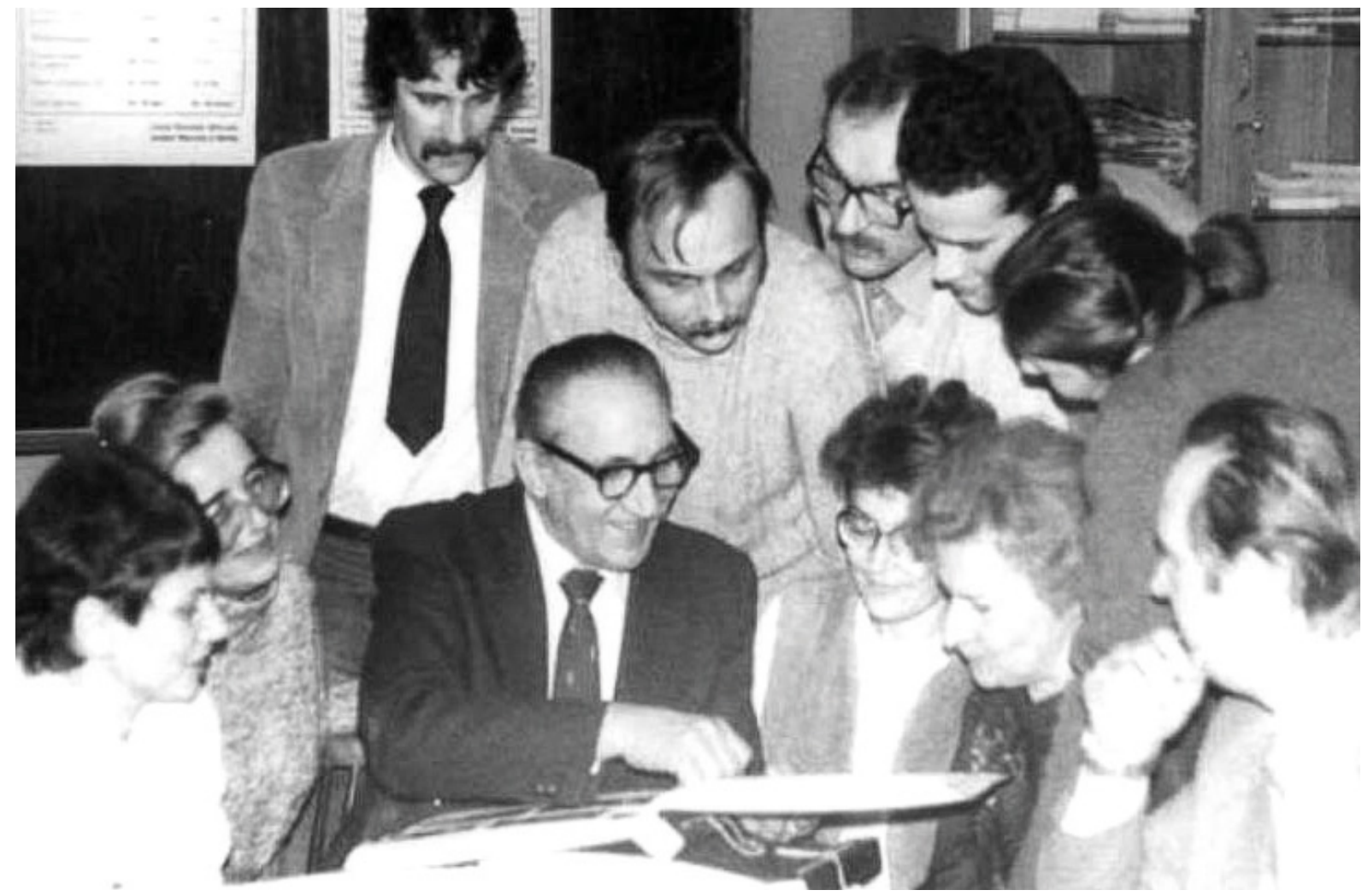

Prof. Stefan Raszeja with his students

times he lived. His incomparable progress in work affirmed the meaning of the ancient words:

\section{There is nothing}

\section{is permanent except change.}

\section{- Heraclitus}

We live and die, sometimes leaving behind more intellectual value than others, as Professor Raszeja did. Courage, self-discipline, justice and wisdom are well-known and timeless virtues of life. Looking at the heritage of professor Stefan Raszeja, we had the impression that all these virtues can be found in his work. He was born in 1922 in a family of teachers. At the start of World War II he was part of the Tajna Organizacja Wosjkowa "Gryf Pomorski" (Secret Military Organization "Pomeranian Griffin") and fought against the occupying German army Pomeranian region [3]. In the later part of the war he joined to the brave Home Army, the dominant resistance movement in Poland. We can only assume that his combat and wartime experiences imprinted the importance of those four virtues in professor's mind. "The path of least resistance is a terrible teacher" seems to be the reason to take the lesson of his achievements de- spite impediments. Numerous publications about various aspects of medicine reflect prof. Raszeja's devotion to hard work and finally the versatile proficiency in forensic medicine and ethics [4]. In the field of forensic medicine his interests focused on the pathological changes caused by mushroom poisoning, population genetics, identification of biological traces for the purposes of crime investigation, the biochemistry of dying and brain death diagnosis criteria for the purposes of organ transplantation. Professor Stefan Raszeja skilfully combined his scientific work with didactics and far-reaching organisational work which led to the growth and development of the Deparment of Forensic Medicine at our University. Six of his students went on to become full professors, 7 earned doctor habilis degrees and 9 defended their doctorates. He frequently stated that every teacher, especially professor, should be judged by his students, who should surpass their mentor [4]. His words mirrors nothing but the ideal relationship between a mentor and student, free of competition and jealousy. In fact, splendour is attributed to our self-reliant students and passed on to next generations.

One repays a teacher badly if one always remains nothing but a student. 
Prof. Raszeja was not just a teacher of medical ethics but someone who put those values and rules into direct action. In 1978 prof. Raszeja formed and chaired the Ethics Committee at the MUG, the first such institution in Poland, which later served as a blueprint to form them at all medical universities in Poland [5]. Professor Stefan Raszeja's achievements were recognized with numerous national, military and scientific awards [3]. After retirement from his position as Head of the Department, prof. Raszeja remained profesionally active, continued to publish research articles and to review medico-legal reports written by his fellow forensic medicine specialists. His attitude is a model worth imitating. Prof. Raszeja belongs to the generation of exceptional professors, whose knowledge, skills and values left a permanent mark on science.

In an interview published last year, asked for the receipe for longevity, he reminded that two factors are required: activity and the need to be active. His words are becoming even more prominent in the era the Internet when the access to information is so easy. By that means, prof. Raszeja left us the timeless message: have a goal and undertake the actions needed to achieve it.

\section{Just that you do the right thing.}

\section{The rest doesn't matter.}

\section{- Marcus Aurelius}

Professor's closest associates/co-workers remember him as a benevolent, charismatic and kind person [3]. From the EJTCM perspective, continuators of his editorial work, the unforgettable prof. Stefan Raszeja remains in our mind as an authority. He was interested in progress of the journal, always willing to help his successors. At his last years he struggled to climb the stairs to EJTCM Office and was the awaited mentor there. Let prof. Raszeja's physical struggle to achieve our common editorial goals remain an example to others.

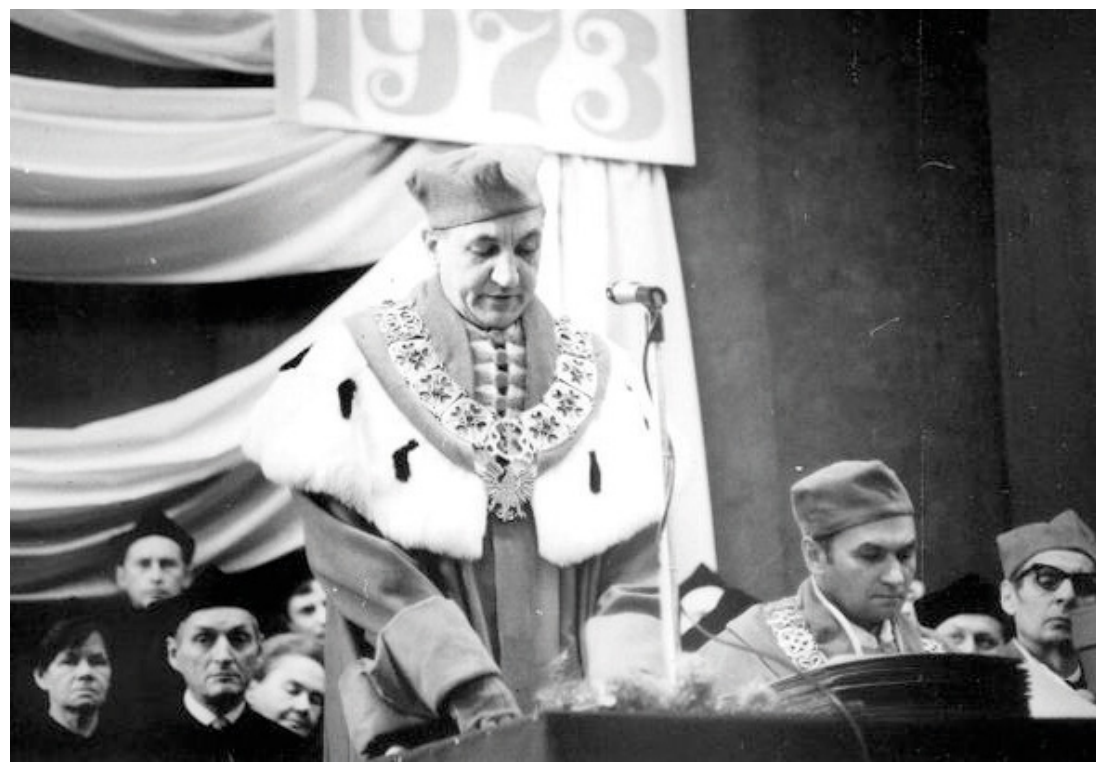

Prof. Stefan Raszeja MD PhD as the MUG Rector - 1972/73 r.

\section{References}

1. Kozłowski D. Quo vadis Annales? Eur J TransI Clin Med [Internet]. 2018;1(1):7. Available from: http://dx.doi.org/10.31373/ ejtcm/92190

2. Szmuda T, Kozłowski D, Springer J, Omilian-Mucharska M. EJTCM w Scopusie [in Polish]. Gaz GUMed. 2021;31(6). Available from: https://gazeta.gumed.edu.pl/attachment/attachment/76469/Gazeta_GUMed_czerwiec_2021.pdf

3. Szczerkowska Z, Jankowski Z, Kaliszan M. Prof. Stefan Raszeja. Wspomnienia pośmiertne [in Polish]. Gaz GUMed [Internet]. 2021;31(5):25-7. Available from: https://tinyurl.com/gazetaczerwiec2021

4. Jankowski Z, Szczerkowska Z. Profesor Stefan Raszeja - w 80. rocznicę urodzin. Gaz AMG [Internet]. 2003;13(2):25-7. Available from: https://gazeta.gumed.edu.pl/attachment/attachment/71373/GazAMG 2003 nr2.pdf

5. Raszeja S. Bioetyka badań naukowych w medycynie [in Polish]. In: Budyńko $Ł$, Waszak P, editors. Pomysł - badanie - publikacja Poradnik naukowy dla studentów kierunków medycznych [Internet]. Gdańsk: Gdański Uniwersytet Medyczny; 2015. p. 105-23. Available from: https://poradnik-naukowy.gumed.edu.pl/attachment/attachment/29059/Pomysl Badanie Publikacja Poradnik naukowy dla studentow kierunkow medycznych.pdf 